\title{
Of private and social in socialist cities: The individualising turn in housing in a medium- sized city in Socialist Yugoslavia
}

Scholars of socialist cities often refer to the gap between the collectivistic ideology underpinning socialist urban planning and the centrality of the private in everyday life. Socialist urban planners and policy-makers maintained that the material basis of the socialist city would produce new social forms and moral values. This ideological starting point was reflected in collective property relations, the expansion of the public sphere, the uniformity of the built environment, standardisation of housing, and communal living in residential neighbourhoods. ${ }^{1}$ Historical and anthropological studies of socialist urbanity in Eastern Europe have noted, however, that the collectivist aspirations of socialist urban planners did not materialise. On the one hand, the implementation of urban planning clashed with the material contingencies of presocialist cities, the prioritisation of heavy industry over urban development, and massive ruralto-urban migration. ${ }^{2}$ On the other hand, the state's authoritarian control of the public sphere forced individuals to withdraw to private realms for individual agency and emotional investment. In actually existing socialist cities, the public and private were infused with diametrically opposing moral categories. ${ }^{3}$

Housing is one of the domains where this binary opposition is most evident. In programmatic accounts of socialist urbanity, the home was socially-owned, standardised, and uniform. Large parts of the functions traditionally ascribed to the household would be transferred to communal units, either the residential building or the neighbourhood. Historical anthropologies of socialist urbanity found, however, that the home in subjective practice was upgraded into a heterotopic private space that was invested with personhood and diametrically opposed the amoral and impersonal public space. In this line of literature, the sharp bifurcation between the private home and the public space forms the "simple geography of socialism", reflecting the political and ideological fault-lines between public and private cutting across socialist societies. ${ }^{4}$ This 
private-public reconfiguration was also evident in property relations. Although programmatic prospects of socialist urbanity marginalised private property, detached houses in private ownership remained commonplace all over Socialist Eastern Europe. This is broadly understood as an indicator of the preference of broad parts of the population for private ownership and the failure of state-sponsored urbanisation programmes. ${ }^{5}$

The dualist housing sector in Socialist Yugoslavia is a particular variation on this theme. Parallel to the split with the Soviet Union, Yugoslavia developed its own form of Socialism under the banner of social self-management. The country politically and ideologically distanced itself from so-called state administrative socialism of the Soviet Bloc and delegated ownership to society as a whole. Economic decision-making was decentralised from state administration to workers' councils, the economy was increasingly liberalised and opened to Western trade, and enterprises were intended to perform according to the logic of the market. ${ }^{6}$ The particular organisation of housing in Socialist Yugoslavia reflects the relatively liberal character of its economy. The so-called social sector was run by enterprises and municipalities and predominantly oriented toward high-rise residential buildings in urban areas. It subscribed to the collectivist underpinnings of modernist urban planning. The private sector evolved in parallel in detached single-family houses in the urban outskirts and the rural areas and largely evaded formal urban planning. The private sector accounted for around $60-70 \%$ of the annual housing production, making the country a trendsetter in socialist Eastern Europe. ${ }^{7}$ A specific feature of private homebuilding in Socialist Yugoslavia was its informal character. Informal individual agency is inherent to urban development in the region, from the squatter settlements in growing interwar cities to middle-class post-socialist suburbs. ${ }^{8}$ Yet, the spatial organisation, material qualities, scope, and durability of informal housing during socialism makes the phenomenon stand out. Entire single-family house settlements rose in the urban peripheries in apparent complete disregard of socialist urban regulations. These settlements provide some sort 
of material and spatial mirror image of the vertical, spacious, and compact social-sector administrative centres and housing estates. ${ }^{9}$

Socialist Yugoslavia was organised as a federal state. Political and economic decisionmaking were decentralised to the six republics and two autonomous regions within the Republic of Serbia. Socio-economic inequalities between the units of the federal state were enormous and continuously grew, regardless of federal funding for the accelerated development of underdeveloped regions. ${ }^{10}$ The Yugoslav development gap was evident in housing as well. In Kosovo, an autonomous region and later province within the Republic of Serbia and the least developed and urbanised unit of the federal state, shares of private homeownership reached $90 \% .{ }^{11}$ Although the province witnessed rapid urbanisation after the Second World War, socialsector urban development was restricted. Census results of 1971 indicate that for Yugoslavia as a whole, the share of social-sector dwellings in cities alone was $38 \%$. In cities in Kosovo, only $20 \%$ of the dwellings was socially-owned. ${ }^{12}$ Social-sector housing was primarily concentrated in the capital Prishtina (Serbian: Priština) and to a lesser extent Mitrovica, the model industrial city of the province. ${ }^{13}$ The limited reach of social-sector urban development converged with ethnic divisions, as Albanians, who made up for the majority of the population in the province, were overrepresented not only among the rural population but also among the private homeowners in cities. ${ }^{14}$ Considering the expulsion/withdrawal of Albanians from the public sphere and ethno-political mobilisation in the 1980s, the open tensions and violent warfare of the 1990s, and the continuing partitioning of Kosovan society along ethno-political fault lines until the present, it seems particularly convincing to project these deep social rifts back onto the social-private duality in socialist cities of Kosovo.

This paper, however, suggests a different reading which challenges the focus on the politicised duality between private and social spheres in socialist cities and explores privatesocial reconfigurations as an integral part of socialist urban development. It is inspired by recent accounts of socialist urbanity that challenge the "failure-centrism" in the scholarship on 
socialist architecture and planning and instead highlight the achievements of socialist urbanisation and housing programmes, the future-oriented endurance of the socialist built environment, and the intimate connections of inhabitants with socialist housing. ${ }^{15}$ This revaluation has particularly strong implications for analysing private-public reconfigurations in socialist cities, as it undermines the sharp private-public division considered characteristic for socialist cities. ${ }^{16}$ Failure-centred studies of socialist urbanity rarely take into account the processual nature of urban development. They evaluate actually-existing socialist cities against a supposedly inert and fixed idea of socialist modernity predicated on anti-Capitalist and antiindividualistic basic tenets. Anna Krylova has recently suggested an alternative view of Soviet socialist modernity that takes into account the dynamics of social and cultural change throughout the twentieth century. She introduced the concept of "post-Bolshevik socialist modernity" to capture alternative individualising discourses of Soviet socialist modernity, which "foreground personal and private aspects of the self and presuppose a differentiation between the self and its social milieu". ${ }^{17}$ This individualising turn also applies to socialist urban planning after the Second World War. Mark B. Smith highlighted the cooperative nature of the mass urban housing programme in the Soviet Union after the Second World War, which integrated individual housing strategies into urban development. ${ }^{18}$ In their programmatic account of post-1945 urban societies in Europe, Smith and Moritz Föllmer argue that individual self-reliance and ownership were an integral feature of urban societies in Eastern Europe as well, notwithstanding the ideological preference for collectivism. ${ }^{19}$

The market-oriented reforms of the mid-1960s in Socialist Yugoslavia are one of the more evident indicators of the individualising turn in socialist urban development after the Second World War. ${ }^{20}$ In this article, I take a closer look at local decision-making processes behind the shifting private-social configurations in a peripheral medium-sized city in Socialist Yugoslavia. In looking for characteristics features of "the socialist city", studies of socialist urbanity tend to focus on capital cities or exemplary new towns, thereby excluding the particular experiences of 
so many small and medium-sized socialist cities. I argue that local decision-making in smaller peripheral cities demonstrates the open-ended character of socialist urban planning and the constant negotiation between individual housing strategies and planning measures by local actors, including professional urban planners, local party representatives, and enterprises. This article presents the case-study of Mitrovica, a medium-sized city in Kosovo. In terms of size and political relevance, the city was of secondary importance in Socialist Yugoslavia. For Kosovo, however, Mitrovica was the model industrial city as the seat of the high-priority mining, metallurgy, and chemical industry enterprise Trepça (Trepča). The city’s population grew rapidly from less than 15,000 after the Second World War to over 50,000 in the 1980s. The prioritised access of Trepça to central funding was reflected in the, at least for Kosovan standards, intensive urban development and large share of social-sector housing. The monopolistic hold of Trepça on social-sector urban development concentrated social-sector housing in a compact zone of priority on the less densely built terrain north of the Ibër (Ibar) River. The enterprise had the last word in housing allocation, which resulted in sociooccupational overrepresentation of management cadres and technical specialists in the northern part of the city. ${ }^{21}$ On the other side of the river, socialist urbanisation relied on the degradation of Mitrovica's Ottoman-era commercial and residential centre. The reconstruction of the Ottoman city centre went underway in the second half of the 1970s but remained fragmentary and layered. Massive migration to the city greatly surpassed the capacities of social-sector house construction. In such conditions of under-urbanisation, rural migrants resorted to informal homebuilding in single-family house settlements in the urban periphery. These were primarily located on the greenfield sites to the southwest of the city centre. ${ }^{22}$ Based on embedded research of archival sources of the municipality and local press, this article explores shifting social understandings of private- and social-sector urban development from the late 1950 s until the early 1980 s. 


\section{Private-sector homebuilding: From illegal to wild}

In 1962, the municipal authorities of Mitrovica for the first time discussed "illegal" individual homebuilding. Over 200 cases of illegal building had been registered in 1960 and 1961. The report found that most of these houses were built by rural-to-urban migrants, for whom it was argued that they had sufficient means for private homebuilding in line with municipal regulations and that they were well aware of the building requirements, but nevertheless opted for informal house construction. They built houses themselves, using low-quality timber and self-made brick. The houses were of low hygienic standards and often poorly isolated, and formed "settlements with the rough contours of scattered houses without order and adequate roads". ${ }^{23}$ These individual building activities jeopardised the orderly development of the city and brought "primitive" standards and "the ambient of the village into the city". ${ }^{24}$ The discourse used in the report, which labelled individual homebuilding "illegal", "primitive", and "rural", clearly excluded individual homebuilders from the normative space and time of socialist urbanity.

Actual practice was, however, more ambiguous than the report suggests. The municipal authorities ordered informal homebuilders to suspend construction and pay a relatively low fine, but rarely went over to demolition. In 1961, for example, only nine informal houses were actually demolished. ${ }^{25}$ In the 1960 s, informal house construction remained stable at around 200 registered new houses per year. It seldom, if ever, came to demolition, even in those cases where the court ordered so. ${ }^{26}$ How should we explain the lenient politics of the local authorities? Were they caught off guard by the subversive practices and Eigen-Sinn of individual homebuilders? Did they lack sufficient state power or legitimacy and thus opted not to intervene in order to preserve social peace? Recent research has shown that informal homebuilding stood beyond categories of legality and formality and that homebuilders acted outside the framework of socialist urban planning. ${ }^{27}$ This article elaborates on this argument but suggests a slightly different reading, which highlights the reciprocate conformation between individual 
homebuilders and urban planners against the background of the open-ended character and individualising turn in socialist urban planning in the 1960s and 70s.

Local discussions on illegal building took place at the time the municipality was adopting its first general urbanistic plan. ${ }^{28}$ With its focus on compactness, vertical residential building, functional zoning, and neighbourhood-scale social integration, the urban plan in many ways formalised a more collectivist understanding of socialist urbanity, reminiscent of what Krylova would term "Bolshevik modern" socialist urban planning. It was the work of a professional architectural studio from Belgrade, while the actual implementation of the plan was the competence of the newly established municipal office for urbanism. Constant revisions of the general urbanistic plan during the subsequent years and decades indicate that urban planning in socialist cities, as elsewhere in post-war Europe, was open-ended and subject to practical solutions that were "consistent with ideological prescriptions, but ... stretched the boundaries of ideological purity". ${ }^{29}$ Much more than the general urbanistic plan, local discussions surrounding the actual implementation of the plan demonstrate the processual nature and individualising turn in socialist urban thinking. In a context of housing shortage in a small and rapidly growing city, which had limited or no adequate pre-socialist housing and infrastructure, local representatives of the League of Communists found that "the idea that the municipal people's council was obliged to supply a flat to everybody was untenable" and that "it was maybe necessary to secure certain funds for providing credit for private construction". This option was clearly a solution for socially vulnerable parts of the population, with no access to social-sector housing. ${ }^{30}$

In order to comprehend the scope of the housing shortage, it is useful to quote from one of the many reports composed by the municipal commission for housing. When residents made requests for social-sector housing, the commission visited their current flat to confirm whether or not their housing need was urgent. In the case of the Vlašković family, the commission noted that the family lived in one room of less than nine square metres, which had served as a summer 
kitchen. The room was old and decayed and the danger of collapse was real. The humidity and the smell were unbearable. In winter, ice formed in the room. In this case, as in many others, the commission recognised that the family should receive a new flat. ${ }^{31}$ In principle, residents who obtained such a confirmation had priority access to social-sector housing. Given the housing shortage, however, the chances of the Vlašković family were slim. In 1965, for example, it was estimated that there were 3000 residents on the waiting list for social-sector housing, while the municipality and Trepça only constructed 300 new dwellings per year and a substantial part of these went to specialists and management. ${ }^{32}$ This situation caused considerable social dissatisfaction. Already in 1959, the municipality's people's council noted that housing distribution was one of the most urgent and difficult questions, which "we are not even close to solving". ${ }^{33}$ Vojislav Petrović and his family lived in a small and moisty room of three by three metres. With irony and anger, he wrote the commission to finally take his "thousandth" request into account, wondering if it was really normal that he was "poisoning his family in some kind of private cellars in our Socialist common and equal country of today, although I am sure that I and my late parents, brothers, and sisters did not contribute less to this country and the current socialist system and freedom than many of those who received ... flats and who change their home constantly to have a larger flat or for a better quality of living." 34

On the other hand, individual homebuilders did not situate themselves out of the framework of socialist urban development. Historical anthropology shows that individual homebuilders retrospectively couch construction in the language register of Yugoslav socialism and its temporality of linear progression. In other words, they do not make sense of informal homebuilding as an act of subversion undermining formal socialist urbanisation. ${ }^{35}$ Reports by the municipal inspectorate for housing on illegal homebuilders present similar findings. The case of Alit Dženajev, worker in the local catering company, is illustrative. In May 1961, the municipal office for communal and housing affairs ordered Dženajev to "immediately suspend" the construction of a small shed of 7 by 2.5 meters because he could not present an official 
permit for construction and because the shed was located in a zone for high-rise housing. Dženajev started the usual appeal procedures which ultimately took him to the provincial authorities in Prishtina. He first called on his partisan and socialist credentials, explaining that he was a war invalid, production worker, and the only wage earner in a family of eight. He rented a room in a private house, but after being forced out by the owner he saw no other option than to start the construction of a small house. He made clear in his appeal that he had conformed to formal urban development requirements. He had built on his "own piece of land" in an "out-of-the-way street" in the vicinity of other small adobe houses. Moreover, he had tried on several occasion to obtain formal permission for the construction with the municipal authorities, but was repeatedly told to wait until the adoption of the general urbanistic plan. Awaiting an official construction permit, he continued the construction works and moved in with his family. ${ }^{36}$ Dženajev clearly located himself and his home within the normative here and now of socialist urbanity. He was an urban wageworker with partisan credentials. Unlike ruralto-urban migrants, whom the municipal authorities criticised for using the money they had earned in the village - presumably in speculative manners - to move to the city and consciously circumventing urban regulations, Dženajev could legitimately claim the right to housing. He had been forced to rent an expensive room from a private house owner due to the urban housing shortage. He had even conformed to the procedures of socialist urban planning, by officially requesting permission for individual house construction and building his house in a peripheral part of the city, where it would presumably not interfere with long-term social-sector urban development.

By the time the urban plan was adopted in 1963, over 2,000 individuals had formally applied for permission for individual house construction. ${ }^{37}$ Of these, a very limited number actually gained permission, because urban development focussed on high-rise residential buildings in the northern part of the city. Informal individual homebuilders, however, did not completely evade urban planning. They concentrated their building activities in Tavnik, a relatively flat 
greenfield area between the city centre and the villages to the south and southwest of the city, which had been designated as the zone for detached houses from the earliest conceptualisations of urbanistic development in the mid-1950s. Informal homebuilders often bought land just outside the urban area, making use of a legal gap resulting from the sharp differentiation in property regimes between urban and rural areas. Land outside the delineated urban area remained in private ownership, could be sold, and was not subjected to urban construction regulations. Osman Hasani, for example, objected to an order of the municipal inspectorate for housing to suspend "illegal" house construction, stating that the deed of sale for his piece of land in Tavnik had been certified by the district court and that others had confirmed that he could build in the area. ${ }^{38}$ The fact that Hasani could officially buy the land means that it was located outside of the urban area and in principle did not fall under the urban planning requirements.

The negotiations between private homebuilders and the municipality's urban planners had considerable implications for urban development. The municipal authorities repeatedly expanded the administrative urban area in order to integrate compact settlements for individual homebuilding in the urban environment. In the final phase of the adoption of the general urbanistic plan in 1963, for example, the municipality opted to "fit inhabited informal houses into the urbanistic whole". ${ }^{39}$ It enlarged the zone for individual house construction to include the growing informal house settlement in Tavnik. ${ }^{40}$ Owners of informal illegal houses that could not be fit into the urban plan were given the opportunity to remove their houses to the designated zone. ${ }^{41}$ The municipal authorities at the same time warned that there would be no more toleration of informal homebuilding and put in place formal procedures for individual house construction by developing land for individual house construction. ${ }^{42}$ Administrative procedures for obtaining building permits and credit for individual family houses became faster and easier, particularly targeting the most vulnerable strata of the urban population. ${ }^{43}$ In practice, however, the municipality failed to develop sufficient land to cover the enormous demand for urban land 
for individual homebuilding. ${ }^{44}$ In 1966, the municipal assembly once more discussed the issue and decided that those "illegal" houses that could be included into the urban plan - which meant that they were located in designated zones - would not be demolished. ${ }^{45}$ This process was repeated in 1971, when the municipality formally legalised informal houses that were located in areas designated for individual house construction, provided that owners would align their houses with urban construction requirements and pay land development taxes. Owners of informal houses that were not located in designated areas were given the right to rebuild their houses in detached housing areas. ${ }^{46}$ In this process, the municipality repeatedly expanded the urban area, particularly in southward direction. ${ }^{47}$

One important outcome of this constant manoeuvring was that the boundary between city and rural hinterland became blurred, confirming the pre-socialist urban-rural hybridity in the region. ${ }^{48}$ The dual-sector development model of Socialist Yugoslavia sharply differentiated the urban core from its rural hinterland. Public-sector industrial economy, with the corresponding socio-economic benefits of wages, child allowances, housing, consumption, and political representation in local government, were located in urban areas. Nationalisation of land, urban planning, social-sector house construction, and communal development only applied to the urban area. House construction in rural areas remained a private affair with very limited regulations and communal development in rural areas was a matter of so-called selfcontribution. ${ }^{49}$ The urban-rural division also imposed different understandings of public order. Strict regulations for maintaining cleanliness in urban public spaces were introduced as an important element of communal self-management. Traditional hybrid urban-rural practices, such as peasant markets or holding of cattle, were confined or banned from the urban area. ${ }^{50} \mathrm{In}$ the process of expanding the urban area to include informal settlements, the municipality abandoned its earlier principle of strict delineation between rural and urban areas. Residents of the individual house settlements in the urban periphery were allowed to hold cows and cattle. ${ }^{51}$ 
Individual houses that were incorporated in the expanding city were exempted from tight urban construction regulations. ${ }^{52}$

The negotiations between individual homebuilders and urban planners also impacted zones initially foreseen for social-sector development. When discussing the report on illegal homebuilding in 1962 - that is, before the general urbanistic plan was actually adopted - none of the members of the people's council argued for the demolition of the illegal houses, even if they were located outside the designated zones for detached housing. Taking into consideration the financial means and efforts informal homebuilders had put into their houses and the "humanitarian" situation of families - undermining the claim in the report that informal homebuilders were rural-to-urban migrants with sufficient means - the municipal authorities decided that those informal houses that could not be fitted into the urbanistic whole would be tolerated for the time being, provided that the owners agreed to demolish the house themselves when actual construction in line with the urban plan would start. ${ }^{53}$ Informal homebuilders were well aware of this policy. Many quickly built a temporary shed and moved in with their family. They made use of the long appeal procedures against the demolition of illegal houses and in the meantime further constructed their houses, knowing that this would make the actual demolition even less likely. ${ }^{54}$ When negotiating with municipal inspectors, they argued that the appalling conditions in their previous homes (often rooms rented from private owners) had a dramatic impact on the health of their children and forced them to take matters into their own hands. They also guaranteed that they would construct their houses in line with urbanistic requirements and demolish them in due time, should urban development require so. Selman Bejtula, for example, explained that he had been forced to find shelter for his family after their house had been demolished for the construction of the new superphosphate factory. He had built a provisional house while waiting for the construction permission. As soon as he would obtain permission, he would deconstruct the house and build in accordance with urban requirements. ${ }^{55}$ Asan Shaban committed himself to demolishing the house he had built, "without requiring any 
compensation", but requested that he and his family could stay in the house until the need for demolition was urgent. ${ }^{56}$ Mustafa Shala stated that he did not have the money to build a threestorey house, as had been foreseen in the urban plan. Considering his family's urgent need for housing, he had been forced to start building a house of two storeys. In case "financial means and possibilities" would enable him, he would add another floor to the house to make it conform urban planning. ${ }^{57}$ Many also referred to the fact that they built their houses where others had already done so, in areas where the construction of high-rise buildings in line with urban planning did not seem to get underway any time soon. Rista Brozović, for example, had decided to build a detached house, although the municipal authorities had declined his request for construction because the area was designated for high-rise buildings. He countered that "every day, new low-rise houses sprouted up in the area" and that it seemed unlikely that high-rise buildings would be built any time soon. ${ }^{58}$

Municipal authorities were not aloof from these arguments. It was found that it was more cost-efficient to use urbanised land for individual house construction where the short-term prospects for social-sector development were slim. ${ }^{59}$ Informal individual houses that had been temporarily tolerated de facto obtained permanent status, leading to pockets of detached houses in parts of the city that had initially been foreseen for high-rise residential buildings or green spaces. One example of such fluid practices of urban zoning concerns the north-western slope of "Partisan Hill", an area in the northern part of the city that had been designated for green space, recreation, and commemorative practices in the urban plan of 1963. In May 1962, a group of five landowners wrote directly to Petar Stambolić, one of the top figures in the Serbian League of Communists, to intervene on their behalf with the municipal people's council. They had bought land on Partisan Hill that had been located outside the urban area with the purpose to build houses privately. They aligned their private interests with the collective, arguing that they wanted to build their own houses "in order not to burden society". ${ }^{60}$ The municipality initially declined their request, but two years later revised the urban plan - only one year after 
it was adopted - and determined that the area on Partisan Hill would be developed for singlefamily houses with gardens. ${ }^{61}$

The reciprocate integration of individual homebuilding came to a close in the late 1970s, when a new phase of intensive urban development came under way. The label "illegal" was replaced with "wild". There were still complaints about the fact that "residents had built their houses without paying much attention to the urbanistic plan" and that individual house construction had led to the irrational use of land. ${ }^{62}$ However, there was no more mentioning of its incompatibility with long-term urban development or the need to demolish informal housing when urban development required so. In the framework of the general reconstruction of the city taking place at this time (see below), considerable attention was paid to the communal development of informal house settlements as compensation for what was seen as the lack of investment for communal development in these areas. ${ }^{63} \mathrm{New}$ areas for individual homebuilding were developed. Reflecting the typically West-European concept of suburbs, these were praised as having clean air, surely an important asset in the extremely polluted industrial city. ${ }^{64}$ Whereas in the early 1960s, informal homebuilding was excluded from the here and now of socialist urbanity as a primitive and ultimately selfish rural practice, individual house construction by the second half of the 1970s had become an inalienable right of "citizens" and "working people" to use the means they had at their disposal to improve their living conditions. Informal homebuilders were no longer categorised as rural newcomers, but as legitimate socialist urbanites. Moreover, the individual interests of private homebuilders did not clash with the broader collective interest. Rather the opposite, private homebuilders were said to "unburden" society, as they did not occupy social-sector flats and liberated means for housing for the truly needy. ${ }^{65}$ Individual homebuilding thus brought the individual to the foreground while aligning individual interests with collective needs, in a clear example of the individualising turn of socialist urban development. 


\section{Social-sector housing: from soliters to solidarity}

The turn to a more individualist understanding of socialist urbanity was not only evident in the integration and formalisation of individual homebuilding. In this part, I shift the attention to social-sector housing and show how policy changes and reforms reduced the collectivist function and social reputation of social-sector housing. Put schematically, social-sector housing evolved from a privileged site of communal self-management to a social good for redistribution to vulnerable parts of the population. The stand-alone high-rise towers or soliters that had served as the hallmark of urban modernity in early conceptions of socialist urbanisation in the 1960s had become undesired dwellings targeted for solidarity purposes by the 1980s. As with informal homebuilding, I argue that the shifting reputation of social-sector housing was the outcome of the processual nature of local urban development.

Mass urbanisation programmes in the post-Stalinist Soviet Union and its Central and Eastern European satellites introduced a degree of individual ownership unknown in pre-war understandings of socialist urban modernity. This did not amount to a complete shift to radical individualism. In a return to Leninist collectivistic discourse, new urbanistic designs aimed to align individual with collective interests. ${ }^{66}$ The neighbourhood and the residential building played crucial roles in performing the collectivistic functions of the socialist city. ${ }^{67}$ In Socialist Yugoslavia's variation on post-Bolshevik socialist urbanisation, two basic units of social selfmanagement stand out. So-called residential communities gathered residents at the neighbourhood level; house councils in social-sector apartment buildings.

Residential communities provided social and communal services to facilitate the daily lives of households and in particular employed women with children. Part of the aggregate rent went to the residential communities, but in the spirit of Yugoslav self-management, they were expected to become self-sustainable. Residential communities typically organise child care, small household services, and technical reparation services. Through consumers' councils that overlooked the work of shops, they protected the consumption interests of residents. They also 
organised reconciliation councils for solving disputes outside of court. ${ }^{68}$ The residential community was an exclusively urban phenomenon and spatially structured around neighbourhood centres providing social, commercial, and cultural services ${ }^{69}$ Its parallel in rural areas was the local council, which served as a body for rural self-help in communal affairs, but was much less ideologically charged and did not receive any formal support.

Mitrovica's urban plan clearly formulated the neighbourhoods' function to align individual and collective interests. They had the goal to "intensify socio-political life' and "integrate every individual in a constructive endeavour to solve problems of interest for each individual, his residential community, city, and our entire society". ${ }^{70}$ The city was subdivided in two residential communities. Bair comprised the pre-socialist city south of the Ibër. It covered 2/3 of the urban area with around 18,000 inhabitants. Ibar was located to the north of the river and had 9,000 inhabitants. ${ }^{71}$ Residential community Ibar was clearly privileged, comprising the new socialist neighbourhood with its social-sector housing and designated infrastructure for service provision and communal life. The Ottoman-era commercial bazaar across the river was the counter-image of the modern communal environment north of the river. Much like illegal homebuilding at the same time, it was labelled primitive and of poor aesthetic and material quality. The urban plan envisaged the complete demolition of the pre-socialist city and placed it outside the future-oriented here and now of socialist modernity.

It quickly became clear, however, that the collectivistic functions of residential communities remained dead letter. In terms of service provision, the residential communities could not compete with private artisans in the old city centre. They were more expensive and the quality of services was poor due to bad equipment and unskilled workers. Residential communities also did not dispose of adequate infrastructure for service provision, even in the new part of the city where residential buildings included space for stores and shops. The child care centre in Ibar was one of the symbols of socialist urban modernity in the new part of the city, but it was not fully booked. In reality, the socialist neighbourhood continued to rely on the private services 
provided by craftsmen in the old bazaar, although these were constantly tarred for being particularly susceptible to economic crimes (tax evasion, poor labour conditions), poor services, and long waiting times. Modern canteens were one of the emblematic modern services residential communities were supposed to provide, but instead, various private chickpea and seed sellers with deplorable hygienic conditions mushroomed in the city. ${ }^{72}$

The Constitution of 1963 created the local community, a new body for local selfmanagement, which replaced the urban residential communities and the rural local councils. At first sight, local communities seemed to strengthen the collectivistic functions of residential communities. They were defined as voluntary associations of citizens providing assistance in urban (child care, housekeeping, house management, and communal services) and rural domains (maintenance of land and graveyards, protection from natural disasters, and cleanliness).${ }^{73}$ Local communities were heavily ideologised. They served as an important body in the process of the withering away of the state. They provided the framework for direct socialist democracy and the socio-political organisation of citizens by delegating representatives to the municipal assembly. In practice, however, local communities became increasingly intangible. Frequent calls in the local press to intensify the work of local communities show that these had become an ideologically charged but empty box. ${ }^{74}$

Tertiary activities, the most concrete competences of residential communities, were transferred to professional municipal enterprises or private shopkeepers and craftsmen. The loss-making services provided by the residential communities were merged into a new communal enterprise. The child care centre was turned into a social institution directly run by the municipality. ${ }^{75}$ The municipality also started promoting private shops, craftsmen, and markets through beneficial taxation, rent, and credit regimes and the provision of adequate locations in future urban planning (including in the bazaar). It recognised that social-sector shops and services had failed to improve the living standard of the urban population. Similar to informal homebuilding, private shopkeepers partially filled this gap but were working on the 
margins of legality and as a consequence the quality of their work was appalling. The municipality aimed to formalise and legalise private commercial activities and at the same time stepped up inspection against irregularities, in order to increase competition and ultimately quality. $^{76}$

The second site for performing the collectivistic function of social-sector urban development was the apartment building. Per building, tenants elected house councils which were financed from part of the rent. The house councils cared for the maintenance of the building and the public spaces in the house. They were also responsible for rent collection and tenancy contracts. ${ }^{77}$ The councils were particularly tasked with aligning individual and collective interests. They overlooked whether tenants made use of the house in an urbane and civilised manner. Explicitly forbidden were uncivil acts associated with rural life, such as storing goods in the common spaces, using toilets for throwing away garbage, drying laundry on balconies, chopping wood for heating and storing firewood inside the house, keeping animals, and singing and shouting. ${ }^{78}$

The prominent role of house councils in communal self-management remained short-lived, however. Parallel to the professionalization of services provided by residential communities, the housing reforms of 1965 transferred much of the competences and financial means of house councils to newly established municipal housing enterprises. The municipal housing enterprise became a crucial player in the reformed housing market. It managed the social-sector housing stock in the municipality on the basis of market principles. It was tasked to charge marketconform rents, buy and sell real estate, and invest in social-sector housing in a profitable manner. Judging by the primary objective of the housing reforms to improve the quality of social-sector house management and increase social-sector house construction, the market reforms failed badly. ${ }^{79}$ The number of new social-sector dwellings in Mitrovica stagnated and then dropped completely in the early 1970s. Mitrovica's local press noted that the municipal housing enterprise did not have financial means, that it failed dramatically to collect rents, and 
that the quality of maintenance was appalling. ${ }^{80}$ Trepça was the sharpest critic of the market orientation in social-sector housing. The enterprise was the main shareholder in the municipal housing enterprise, owning over $70 \%$ of the social-sector housing stock, and relied on the construction and maintenance of social-sector housing for the attraction of badly-needed specialists. It was thus particularly hit by the poor work of the housing enterprise. ${ }^{81}$

The changing power relations in local urban development created new coalitions, roughly aligning Trepça with the larger dissatisfied urban population against the municipal housing enterprise and a small elite profiteering from the socialist housing market. The former appropriated a more individualising understanding of socialist urbanity, which combined the private interests of the large majority with collective solidarity. In the early 1970s, Trepça's factory journal organised a questionnaire among the workforce to discuss the privatisation of the social-sector housing stock as a way out of the impasse. ${ }^{82}$ Respondents were unanimous in criticising the work of the housing enterprise. It was said that the enterprise was only interested in collecting rent, but did not provide quality services in exchange. All respondents supported the idea that Trepça would privatise its flats and a large majority of them expressed willingness to buy enterprise flats provided that Trepça would give favourable loans. Two types of respondents had no intentions to buy a flat. Specialists, who often came from outside the region and did not plan to stay with the enterprise, were not interested in buying real estate. These were indeed the primary target group of social-sector housing in the late 1950s and early 1960s. A second group consisted of those who had their own houses in the city or the rural hinterland and did not see the need to move to a flat.

The latter group set the standard for many of their fellow workers. A returning argument made by the respondents for the privatisation of the enterprise's housing stock was that inhabitants would take better care of private homes. Many stated that they preferred a detached or low-rise house over a flat in a high-rise tower. They complained that the maintenance of high-rise residential buildings was below standard and living conditions were hard (complaints 
about the lack of water and dysfunctional elevators were particularly frequent). They preferred to have their own house and garden, because this provided more security and a sense of ownership. A second argument for privatisation made by the respondents linked private homeownership to social justice. The enterprise could use the funds obtained through the privatisation to build houses for those workers who had not gained access to social-sector housing.

This point is crucial for understanding the shifts in social-sector housing. Social justice had been an intrinsic element of the housing reforms of the mid-1960s. Market-based urban development was expected to redistribute means from the more affluent parts of society essentially those already living in social-sector housing or those willing to pay higher rents for flats of higher comfort - to the larger part of society that had not gained access to socialist urbanity. ${ }^{83}$ The sharp increase of communal and rental prices and the decline of new houses in social ownership, however, made such redistribution increasingly unlikely. Particularly problematic for the socialist state was that industrial production workers were disproportionally represented among the part of the population living in substandard housing conditions. ${ }^{84}$

In criticising the housing reforms, Trepça gave expression to workers' dissatisfaction with persistent housing inequalities using the multi-faceted language of self-management. ${ }^{85}$ This is ironic, as the monopolistic hold of Trepça over urban development up to the early 1960s had in fact led to sharp socio-occupational differentiation in the new high-rise housing estates in the northern part of the city. The widespread phenomenon of people moving into enterprise-owned apartments without formal approval indicates the perception of social inequality in the enterprise's housing politics. Particularly frequent were cases of people moving into apartments upon agreement with the former tenant but without notifying the enterprise. In other cases, people simply moved into empty apartments as soon as tenants moved out. House occupiers legitimised their act by referring to their difficult housing situation and their right to housing. Novak Marković, for example, claimed that as a miner with a long service record he had the 
right to move into one of Trepça's enterprise flats in the miners' settlement of Stanterg (Stari Trg), even though he did not have a formal approval. Moreover, he had himself reached an agreement with the previous tenant and was living with his wife, a small child, and a new-born baby in a small one-room flat in appalling conditions. Marković referred to the common practice in Stanterg, where "people move in and out as it pleases them." 86

In the early 1970s, Trepça's factory journal started a public shaming campaign with names and details of people engaged in fraudulent transactions with the enterprise's housing stock. Feeding the social dissatisfaction among the majority of the workforce, the campaign focussed on managers and specialists who had rented out or transferred the right to use their flat to family members or acquaintances after moving away or receiving a new flat. Many had also received credit for individual homebuilding, while at the same time renting a flat in social ownership. They abused the lack of political control resulting from the market reforms and used their connections with "responsible people" in the municipal housing enterprise for private enrichment. ${ }^{87}$ In response to the combined concerns of social inequality and fraud in socialsector housing and the apparent failure of market-oriented housing reforms, the League of Communists reaffirmed the need for political control over housing in defence of the interests of the large part of society that had been disadvantaged in social-sector housing. The key word was solidarity. Not only should tenants of social housing contribute to expanded production by paying higher communal costs, socially-vulnerable groups should also gain access to housing at favourable conditions. ${ }^{88}$

In the second half of the 1970s, solidarity became an integral part of a new phase of urban development in Mitrovica. A substantial part of investments in social-sector high-rise buildings targeted vulnerable layers of the population who had been on waiting lists for social-sector housing for years. By this time, social-sector housing had degraded, however, to the bottom of the urban hierarchy, in terms of appreciation of aesthetics and living quality. The urban reconstruction plan of the late 1970s and early 1980s foresaw the preservation and 
reconstruction of part of the old bazaar, which had been excluded from socialist modernity in the early 1960s, but was now praised as the "calm part of the city" and served to "break the greyness the city due to the construction of new residential buildings". ${ }^{89}$ Solidarity housing estates were located in zones of low priority. The miners' settlement of Tunel i parë (Prvi Tunel) was reconstructed for solidarity purposes but remained poorly connected to urban utilities and provisions. ${ }^{90}$ Another block of "solidarity" buildings was located at the old brickworks site, which continued to serve as the central site for the production and transport of cement and concrete for the ongoing road works. The residents complained about dust and noise pollution and about dysfunctional central heating and elevators. ${ }^{91}$

\section{Conclusion}

By reconstructing local decision-making in the domain of urban planning in the peripheral and medium-sized city of Mitrovica, I have shown the open-ended character of socialist urban development and its compatibility with individualising discourses of modernity. The urban plan of 1963 reflected the dogmatic collectivistic understanding of socialist urbanity, but was revised in the actual practice of urban planning and in fact had limited relevance in urban development. The processual nature of socialist urban development led to the reconfiguration of private and social-sector urban development. The gradual upgrade of private housing and parallel downgrading of social-sector housing was not the outcome of popular subversive strategies and the failure of collectivistic socialist urban planning. It reflected shifting negotiations at the local level between residents and local actors involved in urban planning, within the structural framework of market-oriented policy reforms coming from the Yugoslav central level and under-urbanisation. Private housing in the urban peripheries was integrated in the urban fabric as the legitimate right of workers to pursue their own individual interests while at the same time liberating means for the collective to invest in social-sector housing for the truly needy. In this process, the boundaries between urban and rural territories and the moral categories ascribed to 
both were blurred and individual house settlements occupied zones initially foreseen for highrise social-sector housing. At the same time, market-oriented reforms in the management of social-sector housing reduced the collectivistic functions of social-sector housing and created new lines of division between local actors involved in urban planning. Trepça mobilised the dissatisfaction among the workforce about housing inequality and criticised a small elite who profiteered from market reforms in social-sector housing. In the final phase of socialist urban development in the second half of the 1970s, political control over social-sector urban development was restored, but the social-private hierarchy had shifted. Social-sector housing blocks were located in low-priority zones and targeted the most vulnerable strata of the urban population, whereas detached housing settlements guaranteed pleasant living conditions and security for the large middle strata of urban residents. 
${ }^{1}$ Helmut Altrichter, "Living the Revolution: Stadt und Stadtplannung in Stalins Russland", in Utopie und politische Herrschaft im Europa der Zwischenkriegszeit, Wolfgang Hardtwig, ed. (Munich, Oldebourg: 2003): 57-75; Jack C. Fischer, "Planning the City of Socialist Man", Journal of the American Institute of Planners 28, no. 4 (1962): 251-65; Richard A. French and Frederick E. Hamilton, “Is There a Socialist City?”, in The Socialist City: Spatial Structure and Urban Policy, Richard A. French and Frederick E. Hamilton, eds. (Chichester: Wiley, 1979): 1-21.

${ }^{2}$ Thomas Bohn, Minsk - Musterstadt des Sozialismus. Stadtplanung und Urbanisierung in der Sowjetunion nach 1945 (Cologne: Böhlau, 2008); Heather Dehaan, Stalinist City Planning: Professionals, Performance, and Power (Toronto: University of Toronto Press, 2013); Donald Filtzer, The Hazards of Urban Life in Late Stalinist Russia (Cambridge: Cambridge University Press, 2010); Stephen Kotkin, Magnetic Mountain: Stalinism as Civilisation (Berkeley: University of California Press, 1997); David M. Smith, "The Socialist City”, in Cities After Socialism: Urban and Regional Change and Conflict in Post-Socialist Societies, Gregory Andrusz, Michael Harloe, and Ivan Szelenyi, eds. (Oxford: Blacwell, 1996): 70-99; Ivan Szelenyi, Urban Inequalities under State Socialism (Oxford: Oxford University Press, 1983); Kimberly E. Zarecor, Manufacturing a socialist modernity: Housing in Czechoslovakia, 194560 (Pittsburgh: University of Pittsburgh Press, 2011).

${ }^{3}$ Victor Buchli, An Archaeology of Socialism (New York: Berg, 1999); Susan Gal and Gail Kligman, The Politics of Gender after Socialism (Princeton: Princeton University Press, 2000): 37-62; Sonia Hirt, Iron Curtains: Gates, Suburbs and Privatisation of Space in the PostSocialist City (Chichester: Wiley-Blackwell, 2012): 17-29.

${ }^{4}$ Krisztina Fehérváry, Politics in Color and Concrete. Socialist Materialities and the Middle Class in Hungary (Bloomington and Indianapolis: Indiana University Press, 2013): 16-19, quotation on 16; Ekaterina Gerasimova, "Public Privacy in the Soviet Communal Apartment", 
in Socialist Spaces: Sites of Everyday Life in the Eastern Bloc, David Crowley and Susan Reid, eds. (Oxford: Berg, 2002): 207-230; Susan Reid, “The Meaning of Home: 'The Only Bit of the World You Can Have to Yourself"”, in Borders of Socialism: Private Spheres of Soviet Russia, Lewis Siegelbaum, ed. (Basingstoke: Palgrave Macmillan, 2006): 145-70. ${ }^{5}$ József Hegedüs and Iván Tosics, “Conclusion: Past tendencies and recent problems of the East European housing model", in The Reform of Housing in Eastern Europe and the Soviet Union, Bengt Turner, József Hegedüs, and Iván Tosics, eds (London and New York: Routledge, 1992): 318-34; Sasha Tsenkova, Housing Policy Reforms in Post-Socialist Europe: Lost in Transition (Heidelberg: Physica, 2009): 30-32, 38-41.

${ }^{6}$ Dejan Jović, Yugoslavia: A State that Withered Away (West Lafayette, IN: Purdue University Press, West Lafayette, 2009); John R. Lampe, Yugoslavia as History: Twice There Was a Country, $2^{\text {nd }}$ edition (Cambridge: Cambridge University Press, 2000): 233-298.

${ }^{7}$ Srna Mandic, "Reformism in Yugoslavia: Introductory Remarks", in The Reform of Housing in Eastern Europe and the Soviet Union, Bengt Turner, József Hegedüs and Iván Tosics, eds (London and New York: Routledge, 1992): 299-303.

${ }^{8}$ Kiril Stanilov and Luděk Sýkora, "Postosicalist Suburbanization: Patterns and Dynamics, a Comparative Perspective", in Confronting Suburbanization: Urban Decentralisation in Postsocialist Central and Eastern Europe, Kiril Stanilov and Luděk Sýkora, eds. (Chichester: Wiley-Blackwell, 2014): 256-95; Sasha Tsenkova, "Informal settlements in post-communist cities: Diversity factors and patterns", Urbani izziv 21, no. 2 (2010): 73-84; Zlata VuksanovićMacura and Vladimir Macura, "The Right the Housing: Squatter Settlements in Interwar Belgrade: The Defense and Demolition of Jatagan-mala”, Journal of Urban History 44, no. 4 (2018): 755-74.

${ }^{9}$ Two recent studies of socialist urban development of Belgrade treat informal homebuilding in the capital in detail. Brigitte Le Normand, Designing Tito's Capital: Urban Planning, Modernism, and Socialism in Belgrade (Pittsburgh: University of Pittsburgh Press, 2014): 161- 
83; Nicole Münnich, Belgrad zwischen sozialistischem Herrschaftsanspruch und gesellschaftlichem Eigensinn: die jugoslawische Hauptstadt als Entwurf und urbane Erfahrung [Belgrade between Socialist Claims to Rule and social Eigensinn: The Yugoslav Capital as Plan and Urban Experience] (Wiesbaden: Harrassowitz Verlag, 2013): 223-51.

${ }^{10}$ Lampe, Yugoslavia as History, 233-331.

${ }^{11}$ Mandic, "Reformism in Yugoslavia", 299-302; Tsenkova, Housing Policy Reforms, 35, 40-42

${ }^{12}$ Savezni zavod za statistiku, Popis stanovništva i stanova 1971. Stanovi: Stambeni fond u gradovima [Federal Office for Statistics, Census of population and dwellings 1971.

Dwellings: Housing stock in cities], vol. 7 (Belgrade, 1973): 30-32

${ }^{13}$ On socialist urban development in Prishtina, see Florina Jerliu and Vlora Navakazi, "The Socialist Modernization of Prishtina: Interrogating Types of Urban and Architectural Contributions to the City", Mesto a Dejiny 7, no. 2 (2018): 55-74. I use the Albanian writing of place names in Kosovo. I prefer the definite ending -a for feminine place names over the indefinite -ë (Prishtina and Mitrovica, rather than Prishtinë and Mitrovicë, for example). In case of variation, I give the Serbian writing in brackets upon first mentioning. Mitrovica is currently an ethno-politically divided city. The northern part of the city is predominantly Serb and de facto controlled by the Republic of Serbia. The southern part of the city is Albanian majority and falls under the independent but disputed Republic of Kosovo. The official Serbian name of the city is Kosovska Mitrovica.

${ }^{14}$ Hivzi Islami, "Razlike u nivou urbanizacije izmedju stanovništva nacionalnosti Kosova" ["Differences in urbanization level between populations of nationalities in Kosovo"], Geographica Slovenica 10 (1981): 177-83.

${ }^{15}$ For an overview and critique of "failure-centrism" in studies of socialist cities, see Michał Murawski, “Actually-Existing Success: Economics, Aesthetics, and the Specificity of (Still)Socialist Urbanism", Comparative Studies in Society and History 60, no. 4 (2018): 907-37. 
Other works in this direction are Mark B. Smith, Property of Communists: The Urban Housing Program from Stalin to Khrushchev (DeKalb: Northern Illinois University Press, 2010); Susan Reid, “'Palaces in Our Hearts”: Caring for Khrushchevki”, in Architecture, Democracy and Emotions: The Politics of Feeling since 1945, Till Großmann and Philipp Nielsen, eds. (London/New York: Routledge, 2018), chapter 7; Kimberly E. Zarecor, "Infrastructural Thinking: Urban Housing in Former Czechoslovakia from the Stalin Era to EU Accession", in The Housing Question: Tensions, Continuities, and Contingencies in the Modern City, Edward Murphy and Najib B. Hourani, eds. (New York and London: Routledge, 2013): 57-78; Kimberly E. Zarecor, "What Was So Socialist about the Socialist City? Second World Urbanity in Europe", Journal of Urban History 44, no. 1 (2018): 95-117. 16 Caroline Humphrey, "Ideology in Infrastructure: Architecture and Soviet Imagination”, Journal of the Royal Anthropological Institute 11 (2005): 39-58.

17 Anna Krylova, "Soviet Modernity: Stephen Kotkin and the Bolshevik Predicament", Contemporary European History 23, no. 2 (2014): 167-92, quotation on 170.

${ }^{18}$ Smith, Property of Communists.

${ }^{19}$ Moritz Föllmer and Mark B. Smith, "Urban societies in Europe since 1945: toward a historical interpretation", Contemporary European History 24, no. 4 (2015): 475-91, here $483-85$.

${ }^{20}$ Le Normand, Building Tito's Capital, 138-43; Münnich, Belgrad, 205-209.

${ }^{21}$ Michael Gentile and Örjan Sjöberg, "Intra-Urban Landscapes of Priority: The Soviet Legacy”, Europe-Asia Studies 58, no. 5 (2006): 701-729.

22 Pieter Troch, "Socialist Urban Development in Kosovska Mitrovica: Compressed SocioSpatial Duality in a Medium-Sized Industrial City in Yugoslavia's Underdeveloped South" Godišnjak za društvenu istoriju [Annual for social history] 25, no. 2 (2018): 33-61; Pieter Troch and Thomas Janssens, Layers of Time in the Urban Landscape: Visions of Socialist Urbanity in Mitrovica (Berlin: Jovis verlag, 2018). 
${ }^{23}$ People's Council of the Municipality of Mitrovica, "Informacija o bespravnoj gradnji" [Information on illegal construction] (Regional Archive of Mitrovica, fond 6 (municipal assembly) / year 1962 - box 1, further: RAM 6 / 1962-1): 3.

${ }^{24}$ People's Council of the Municipality of Mitrovica, "Informacija o bespravnoj gradnji”, 4. 4.

${ }^{25}$ People's Council of the Municipality of Mitrovica, "Informacija o bespravnoj gradnji”, 811.

${ }^{26}$ Municipal Assembly of Mitrovica, 'Informacija o bespravnoj izgradnji gradjevinskih objekata za period 1966. do 1971. godine' ['Information on illegal construction of buildings between 1966 and 1971'] (RAM 6 / 1971-1).

${ }^{27}$ Le Normand, Designing Tito's Capital, 161-83; Münnich, Belgrad, 223-51.

${ }^{28}$ Architectural studio Iskra, “Generalni urbanistički plan Kosovske Mitrovice” [General urbanistic plan of Mitrovica] (Belgrade, 1962).

${ }^{29}$ Föllmer and Smith, "Urban societies in Europe”, 483.

${ }^{30}$ People's Council of the Municipality of Mitrovica, Minutes of the meeting of 31 January and 3 February 1959 (RAM 6 / 1959-1).

${ }^{31}$ People's Council of the Municpality of Mitrovica, Commission for the Distribution of Dwellings, report of January 24, 1963 (RAM 6 / 1963-31).

32 Municipal Assembly of Mitrovica, "Ocena stanja komunalne privrede u 1964 godine" [Evaluation of the situation in the communal economy in 1964], February 22, 1965 (RAM 6 / 1965-1).

${ }^{33}$ People's Council of the Municipality of Mitrovica, Minutes of the meeting of January 31 and February 3, 1959 (RAM 6 / 1959-1).

${ }^{34}$ Letter by Vojislav Petrović to the People's Council of the Municpality of Mitrovica, Commission for the Distribution of Dwellings, November 26, 1963 (RAM 6 / 1963-31) ${ }^{35}$ Rory Archer, "The moral economy of home construction in late socialist Yugoslavia" History and Anthropology 29, no. 2 (2018): 141-62. 
${ }^{36}$ Appeal from Alit Dženajev to the Construction Inspectorate of the Autonomous Region of Kosovo and Metohija, May 23, 1961 (RAM 6 / 1961-17).

${ }^{37}$ People's Council of the Municipality of Mitrovica, “Informacija o bespravnoj gradnji”.

${ }^{38}$ Housing inspectorate of the Municipality of Mitrovica, Report on Osman Hasani, May 7 , 1962 (RAM 6 / 1962-29).

${ }^{39}$ People's Council of the Municipality of Mitrovica, "Zaključci o bespravnoj gradnji" [Conclusions on illegal building] (RAM 6 / 1962-29).

${ }^{40}$ People's Council of the Municipality of Mitrovica, Minutes of the meeting of February 4, 1963 (RAM 6 / 1963-1); People's Council of the Municipality of Mitrovica, “Odluka o izmenama i dopunama odluke o određivanju užeg građevinskog reona grada Kosovska Mitrovica i naselja gradskog karaktera Zvečana i Vučitrna" [Decision on changes and additions to the decision on the definition of the narrow construction area of the city Mitrovica and settlements with an urban character Zveçan (Zvečan) and Vushtrri (Vučitrn)], Službeni list $A K M O$ [Official Gazette of the Autonomous Region of Kosovo and Metohija] 17, no. 17 (1962): 625-26.

${ }^{41}$ People's Council of the Municipality of Mitrovica, “Zaključak da se gradjanima koji su podigli bespravno stambene zgrade od poslednjeg zaključka NO opštine po ovom pitanju dodele placevi na Tamniku" [Decision that citizens who built illegal residential buildings since the last decision of the People's Council of the municipality on this question receive land on Tavnik] (RAM 6 / 1963-1).

42 People's Council of the Municipality of Mitrovica, "Zaključci o bespravnoj gradnji”; People's Council of the Municipality of Mitrovica, "Rešenje o predaji na trajno korišćenje uz naknadu zemljište opštenarodne imovine" [Decision on commissioning of land in social ownership in lasting use with compensation] (RAM 6 / 1963-1); Municipal Assembly of Mitrovica, "Ocena stanja komunalne privrede u 1964 godine"; Municipal Assembly of Mitrovica, Social plan for 1965 (RAM 6 / 1965-1). 
${ }^{43}$ People's Council of the Municipality of Mitrovica, Minutes of the meeting of March 9, 1964 (RAM 6 / 1964-2). People's Council of the Municipality of Mitrovica, "Konkurs za davanje na korišćenje gradskog zemljišta" [Competition for giving urban land for use] (RAM 6 / 196621). The municipality gave priority to long-term urban residents, responding to frequent criticism that rural-to-urban migrants were favoured. Zvečan, "Reč građana" [Citizens speaking], May 28, 1966, 3; Zvečan, "Kome i kako dati plac" [Whom and how to give land], May 28, 1966, 3; Zvečan, "Perkrahja reformes dhe kritika e hapert" [Support for the reforms and open criticism], August 27, 1966, 4.

${ }^{44}$ In 1965, the municipality received 700 requests for land for individual homebuilding, but could grant only 80 permits for lack of developed land. Zvečan, "Kush asht fajtor per ndertimin e shtepive pa leje" ['Who is to blame for the illegal construction of buildings'], November 5, 1966, 3 .

${ }^{45}$ Zvečan, "Bespravna gradnja” ["Illegal building”], November 12, 1966, 1.

${ }^{46}$ Municipal Assembly of Mitrovica, “Odluka o posebnim uslovima, načinu i merama za regulisanje bespravno podignutih objekata" [Decision on particular conditions, ways, and measures for the regulation of illegally constructed objects], Službeni list SAPK [Official Gazette of the Socialist Autonomous Province of Kosovo] 26, no. 31 (1971): 663-65; Trepča, "Divlja gradnja: Građevinska dozvola ili rušenje” [Wild building: Construction permit or demolition], June 15, 1972, 9.

${ }^{47}$ People's Council of the Municipality of Mitrovica, Minutes of the meeting of February 4, 1963 (RAM 6 / 1963-1); People's Council of the Municipality of Mitrovica, “Odluka o izmenama i dopunama odluke o određivanju užeg građevinskog reona"; Municipal Assembly of Mitrovica, Letter to the Provincial Assembly of Kosovo, April 15, 1965 (RAM 6 / 1965-1); Municipal Assembly of Mitrovica, “Odluka o urbanističkom razvitku Šipolja, Žabara, Zubinog Potoka, Mokre Gore, usputnog zemljišta jadranske magistrale, ibarskog puta i puta za Srbicu na području opštine Kosovska Mitrovica” [Decision on the urbanistic development of Shipol 
(Šipolje), Zhabarë (Žabare), Zubin Potok, Mokra Gora, the land along the Adriatic Magistrale, the Ibër Road and the road to Skenderaj (Srbica) on the territory of the municipality of Mitrovica], Službeni list SAPK 26, no. 31 (1971): 667-68.

${ }^{48}$ Wolfgang Höpken, "Die Südosteuropäische Stadt” [The Southeast European City], in Urbanisierung und Stadtentwicklung in Südosteuropa vom 19. bis zum 21. Jahrhundert

[Urbanisation and Urban Development in Southeast Europe from the $19^{\text {th }}$ to the $21^{\text {st }}$ Century], Thomas Bohn and Marie-Janine Calic, eds. (Munich: Otto Sagner, 2010): 67-91.

${ }^{49}$ People's Council of the Municipality of Mitrovica, “Odluka o usmeravanju i odredjivanju uslova stanbene izgradnje na području naseljenog mesta Kosovska Mitrovica” [Decision on guidance and definition of conditions for residential construction on the territory of the settlement Mitrovica'] (RAM 6 / 1958-1); People's Council of the Municipality of Mitrovica, "Odluka o uslovima za izgradnju stambenih zgrada na selu" [Decision on conditions for the construction of residential buildings in the village], Službeni list AKMO 17, no. 10 (1962): 34042.

${ }^{50}$ Municipal Assembly of Mitrovica, "Odluka o održavanju čistoće na teritoriji opštine Kosovska Mitrovica" [Decision on the maintenance of cleanliness on the territory of the municipality Mitrovica], Službeni list APKiM [Official Gazette of the Autonomous Province of Kosovo and Metohija] 23, no. 21 (1968): 607-11; People's Council of the Municipality of Mitrovica, "Odluka o držanju domaćih životinja i pernate živine na području grada Kos. Mitrovice, naselja Zvečan, Stari Trg i Prvi Tunel” [Decision on keeping of pets and poultry on the territory of the city Kos. Mitrovica and the settlements Zveçan, Stanterg (Stari Trg), and Tunel i parë (Prvi Tunel)], Službeni list AKMO 16, no. 13 (1961): 375-76.

${ }^{51}$ Municipal Assembly of Mitrovica, “Odluka o izmeni i dopuni odluke o držanju domaćih životinja i pernate živine na području grada Kosovska Mitrovica i prigradskih naselja Zvečan, Stari Trg i Prvi Tunel" [Decision on changes and additions to the decision on keeping of pets 
and poultry on the territory of the city Mitrovica and the settlements Zveçan, Stanterg, and Tunel i parë], Službeni list APKiM 20, no. 47 (1965): 1561-62.

${ }^{52}$ People's Council of the Municipality of Mitrovica, Decision of 9 March 1964 (RAM 6 / 1964-2).

${ }^{53}$ People's Council of the Municipality of Mitrovica, "Zaključci o bespravnoj gradnji”.

54 Municipal Assembly of Mitrovica, "Informacija o bespravnoj izgradnji gradjevinskih objekata za period 1966. do 1971. godine".

${ }^{55}$ Housing inspectorate of the Municipality of Mitrovica, Report on Selman Bejtula, November 9, 1962 (RAM 6 / 1962-29).

${ }^{56}$ Housing inspectorate of the Municipality of Mitrovica, Report on Asan Shaban, July 11, 1962 (RAM 6 / 1962-29).

${ }^{57}$ Housing inspectorate of the Municipality of Mitrovica, Report on Mustafa Shala, May 30, 1962 (RAM 6 / 1962-29).

${ }^{58}$ Housing inspectorate of the Municipality of Mitrovica, Report on Rista Brozović, June 12, 1962 (RAM 6 / 1962-29).

${ }^{59}$ Municipal Assembly of Mitrovica, “Ocena stanja komunalne privrede u 1964. godine”.

${ }^{60}$ Letter by Ilija Aksentijević to Petar Stambolić, May 17, 1962 (RAM 6 / 1962-3).

${ }^{61}$ People's Council of the Municipality of Mitrovica, Meeting of July 28, 1964 (RAM 6 / 1962-3).

${ }^{62}$ Komuna, list za komunalna i stambena pitanja [The Commune, journal for communal and housing questions], "Tamnik se urbanizuje” [Tavnik is urbanised], August 22, 1978, 13; Komuna, list za komunalna i stambena pitanja, "Svojim dinarom do svog krova" [Getting your own roof with your own money], June 25, 1980, 5.

${ }^{63}$ Komuna, list za komunalna i stambena pitanja, "Tamnik se urbanizuje".

${ }^{64}$ Komuna, list za komunalna i stambena pitanja, "Kako do vlastitog stana" [How toyou're your own house], November 1, 1978, 6-7. 
${ }^{65}$ Komuna, list za komunalna i stambena pitanja, "Svojim dinarom do svog krova".

${ }^{66}$ Smith, Property of Communists.

${ }^{67}$ On the neighbourhood and residential building as crucial sites for aligning collective and individual interests in Soviet cities from the late 1950s onwards, see Susan Reid, "Building Utopia in the Back Yard: Housing Administration, Participatory Government, and the Cultivation of Socialist Community", in Mastering Russian spaces: Raum und Raumbewältigung als Probleme der russischen Geschichte, Karl Schlögel, ed. (Munich: R. Oldenbourg, 2011): 149-85.

68 “Opći zakon o stambenim zajednicama” [General Law on residential communities], Službeni list FNRJ [Official Gazette of the Federal People's Republic of Yugoslavia] 15, no. 16 (1959): $353-68$.

${ }^{69}$ Le Normand, Building Tito's Capital, 85-102; Münnich, Belgrad, 152-79.

${ }^{70}$ Iskra, “Generalni urbanistički plan Kosovske Mitrovice”, 17.

${ }^{71}$ People's Council of the Municipality of Mitrovica, Minutes of the meeting of February 22, 1960 (RAM 6-1961/1).

${ }^{72}$ People's Council of the Municipality of Mitrovica, "Informacija o radu stambenih zajednica" [Information on the work of residential communities] (RAM 6 / 1962-2); Council of Work Communities of Mitrovica, Minutes of the meeting of February 22, 1965 (RAM 6 / 1965-1).

${ }^{73}$ People's Council of the Municipality of Mitrovica, "Statut opštine Kosovska Mitrovica" [Statute of the Municipality of Mitrovica], Službeni list APKiM 19, no. 39 (1964): 1052-80.

${ }^{74}$ Zvečan, "Mesto i uloga mesne zajednice" [The place and role of the local community], November 5, 1966, 3; Zvečan, "Konsolodimi i bashkesive locale" [The consolidation of local communities], September 9, 1967, 2; Zvečan, "Jača uloga mesnih zajednica" [A stronger role for local communities], April 10, 1971, 3.

${ }^{75}$ Municipal Assembly of Mitrovica, Decision of March 18, 1965 (RAM 6 / 1965-1). 
${ }^{76}$ Municipal Assembly of Mitrovica, "Informacija o stanju i razvoju tercijarnih delatnosti" [Information on the situation and development of tertiary activities] (RAM 6 / 1966-1). 77 “Zakon o stambenim odnosima” [Law on residential relations], Službeni list FNRJ 15, no. 16 (1959): 359-77.

78 People's Council of the Municipality of Mitrovica, “Odluka o kućnom redu u stanbenim zgradama na području opštine Kosovska Mitrovica” [Decision on house order in residential buildings on the territory of the municipality of Mitrovica], Službeni list AKMO 15, no. 17 (1960), 361-63; People's Council of the Municipality of Mitrovica, “Odluka o kućnom redu” [Decision on house order], Službeni list AKMO 16, no. 1 (1961): 21-23. The discourse of rural incivility continues to dominate understandings of Southeast European urbanity. See Azra Hromadžić, "Streets, Scum and People: Discourses of (In)Civility in Postwar Bihać, Bosnia and Herzegovina", Anthropological Theory 18, no. 2-3 (2018): 326-56.

${ }^{79}$ Le Normand, Building Tito's Capital, 138-43; Münnich, Belgrad, 205-209.

${ }^{80}$ Zvečan, "Umesto napred, korak nazad" [Instead of forward, a step backward], June 25, 1966, 1; Zvečan, "Stanari pred sudom" [Tenants before court], July 9. 1966, 3; Zvečan, "Pagesa pake, edhe qeraja nuk paguhet" [Low costs, but even rent is not paid], January 9, 1971, 2.

${ }^{81}$ Trepča, "Stanbena problematika: Ko i kako (ne) gazduje" [Housing problems: Who does (not) manage and how], March 10, 1971, 10; Trepča, "Prazni fondovi za održavanja" [Empty maintenance funds], April 19, 1972, 10.

${ }^{82}$ The following two paragraphs draw on Trepča, "Korisnici o prodaji stanova Kombinata" [Users on selling the flats of the Combine], June 16, 1971, 6-7; June 30, 1971, 7-8; July 9, 1971, 10-11; July 14, 1971, 6.

83 Živorad Kovačević, "Deset godina komunalnog systema" [Ten years of the communal system], Komuna [The Commune] 12, no. 9 (1965): 2-10.

84 “Solidarnost u stambenoj izgradnji i stanovanju" [Solidarity in house construction and housing]. Komuna 20, no. 7-8 (1973): 2-25. 
${ }^{85}$ Goran Musić aptly notes that Yugoslav socialism oscillated between market and political control over the economy. In period of stronger pro-market orientation, workers' selfmanagement was seen as the freedom of workers in a single enterprise to make business decisions and maximise income. When the party aimed for the increased role of planning, emphasis was put on the class dimensions of workers self-management. Goran Musić, "They Came as Workers and Left as Serbs: The Role of Rakovica's Blue-Collar Workers in Serbian Social Mobilizations of the late 1980s", in Socialist Inequalities and Discontent in Yugoslav Socialism, Rory Archer, Igor Duda, and Paul Stubbs, eds (London/New York: Routledge, 2016): 132-54, here 136.

${ }^{86}$ Municipal inspectorate for housing, Report on Novak Marković, December 11, 1963 (RAM 6 / 1963-31).

${ }^{87}$ Trepča, “Za kim zvone zvona” [For whom do the bells ring], May 5, 1972, 9; May 17, 1972, 9; Zvečan, "Pozitivna nastojanja mitrovačkih komunista" [Positive endeavours of Mitrovica's communists], July 27, 1968, 1; Zvečan, "Očiti primeri deformacija" [Overt examples of deformations], August 3, 1968, 1. On housing inequality and social dissatisfaction in Belgrade in the 1980s, see Rory Archer, "Paid For By the Workers, Occupied By the Bureaucrats: Housing Inequalities in 1980s Belgrade”, in Socialist Inequalities and Discontent in Yugoslav Socialism, Rory Archer, Igor Duda, and Paul Stubbs, eds (London/New York: Routledge, 2016): 58-76.

88 Tarik Karavdić, "Deveti kongres SK Jugoslavije i dalji razvoj stambeno-komunalne privrede" [The ninth congress of the League of Communists of Yugoslavia and the further development of residential-communal economy], Komuna 16, no. 4 (1969): 12-15.

${ }^{89}$ Komuna, list za komunalna i stambena pitanja, "Stara čaršija kao nekad” [The old bazaar as it used to be], February 1, 1980, 9.

${ }^{90}$ Komuna, list za komunalna i stambena pitanja, "Prvi Tunel: Gradi se vodovod" [Tunel i parë: Water supply under construction], February 1, 1980, 12. 
${ }^{91}$ Komuna, list za komunalna i stambena pitanja, "Zabeleženo u naselju "Crepociglana":

Nevolje "solidaraca"" [Registered in the "Brickworks" neighbourhood: The troubles of the "solidarci"], August 22, 1978, 7; Komuna, list za komunalna i stambena pitanja, "Mlado naselje - brojni problemi” [Young neighbourhood - Many problems], July 1, 1979, 14. 